\title{
A critical analysis of the foreign services reportable arrangement provision of the Tax Administration Act of South Africa
}

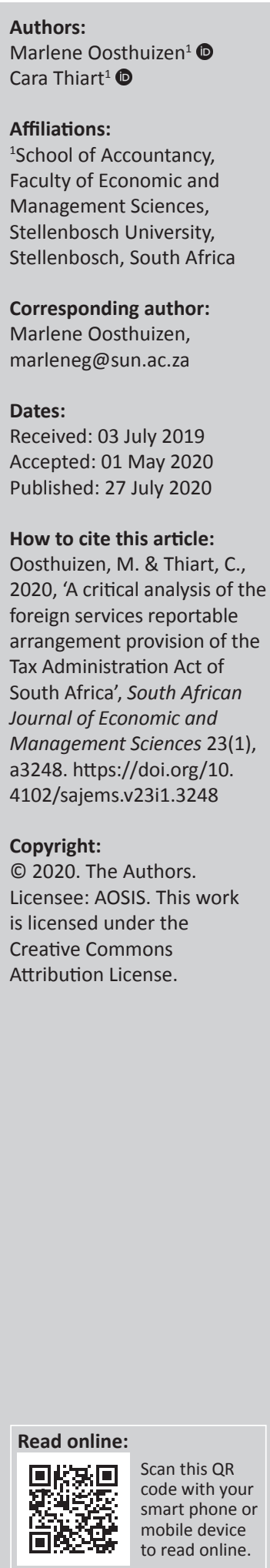

Background: An additional reportable arrangement was added to South African tax legislation by way of a public notice in section 2.6 of the Government Gazette no. 39650 of 3 February 2016 (hereafter referred to as the foreign services reportable arrangement provision). This reportable arrangement relates to service fee payments made by a South African resident (or non-resident with permanent establishment in South Africa) to a nonresident. The services include consultancy, construction, engineering, installation, logistical, managerial, supervisory, technical and training services.

Aim: The aim of this study was twofold: to critically analyse the reportable arrangement provision by examining undefined terminology contained in this provision and to develop a decision tree that may assist taxpayers in the application of this provision.

Setting: Relevant South African literature and tax partners, directors and tax managers at leading audit and legal firms in South Africa.

Methods: The study commences with a review of available South African literature in an attempt to define the terms 'arrangement' and 'anticipated', as applied in the foreign services reportable arrangement provision and continues with survey research to validate some of the conclusions drawn in the literature review.

Results: From the literature review it was determined that although there are South African literature available providing persuasive value to the meaning of some of the undefined terms used in the foreign services reportable arrangement provision, there is no single consolidated source of information which clarifies the exact meaning of the terms in the context of this provision. Hence, survey research was performed to apply the available South African literature in the context of the foreign services reportable arrangement provision. The majority of the respondents in the survey research agreed and validated the assumptions and conclusions drawn from the literature review.

Conclusion: It is therefore submitted that the presented findings may contribute to the limited existing South African literature on the foreign services reportable arrangement provision.

Keywords: Foreign services reportable arrangement; service fee; Government Gazette no. 309650; arrangement; anticipated; Tax Administration Act.

\section{Background and introduction}

In 2013, the Organisation for Economic Cooperation and Development (OECD) issued a report on base erosion and profit shifting (BEPS) which is regarded as the first step towards the review and analysis of BEPS (OECD 2013). Overall, the report identified 15 areas of focus, one of which is Action Plan 12 dealing with mandatory disclosure rules. The OECD explains that the intention of Action Plan 12 is to give countries an extra tool for tackling BEPS by providing tax administrations with early information on cross-border tax planning (OECD 2015a).

In 2017, the National Treasury (2017) explained South Africa's position regarding mandatory disclosure on the OECD action plan by stating that the Tax Administration Act (no. 28 of 2011) contains rules addressing reportable arrangements. Treasury held that these rules require taxpayers who have entered into reportable arrangements, to report the details of these arrangements to the South African Revenue Service (SARS) (National Treasury 2017), who uses the reported details of the reportable arrangements to respond to tax risks through timely risk assessment and audits (OECD 2015a). 
Section 35 of the Tax Administration Act specifies reportable arrangements. While section 35(1) lists specific arrangements, section 35(2) states that any arrangement is considered as reportable if that specific arrangement is listed by the Commissioner in a public notice.

On 03 February 2016 the Commissioner published a public notice constituting a revised list of reportable arrangements in the Government Gazette no. 39650 of 03 February 2016 (South African Revenue Service [SARS] 2016; hereafter referred to as the foreign services reportable arrangement provision). This public notice lists an additional reportable arrangement in section 2.6 pertaining to a particular type of service fee that is paid by a resident (or non-resident with a permanent establishment in South Africa) to a non-resident. These services are defined to include consultancy, construction, engineering, installation, logistical, managerial, supervisory, technical and training services.

The need for this inclusion was the observed increase in cross-border payments, which warranted attention from the SARS (ENS Africa 2015). Significant amounts of money were found to be flowing out of South Africa on an annual basis due to payments for service fees. A task team, known as the Davis Tax Committee, investigated the matter. Their interim report found that $51.60 \%$ of all payments flowing out of the country in 2011 related to legal, accounting and management consulting fees (Davis Tax Committee 2014). Non-residents are only subject to tax with regard to receipts and accruals of income derived from a source in South Africa (in terms of the definition of 'gross income' in section 1(1) of the Tax Administration Act). However, where an international tax treaty is applicable, the service fee income received by the non-resident is only taxable in South Africa to the extent that it has created a permanent establishment in South Africa and the relevant income is attributable to such a permanent establishment. Base erosion occurs when the non-resident service provider fails to register as a permanent establishment in South Africa and does not declare its income that is taxable in South Africa (National Treasury 2013). This could lead to the fiscus being compromised as the resident (or non-resident with a permanent establishment in South Africa) who receives the foreign services would likely claim a tax deduction in terms of section 11(a) of the Tax Administration Act for the expenditure incurred while no corresponding income is taxable in South Africa. Hence, section 2.6 of the foreign services reportable arrangement provision was included as a measure to address this context.

The foreign services arrangement is reportable when it meets all of the following criteria:

2.6 An arrangement for the rendering to a person -

a. that is a resident; or

b. that is not a resident that has a permanent establishment in the Republic to which that arrangement relates, of consultancy, construction, engineering, installation, logistical, managerial, supervisory, technical or training services, in terms of which - i. a person that is not a resident or an employee, agent or representative of that person-

(aa) was or is physically present in the Republic; or

(bb) is anticipated to be physically present in the Republic, in connection with or for purposes of rendering those services; and

ii. the expenditure in respect of those services under that arrangement -

(aa) incurred or to be incurred, on or after the date of the publication of this notice, exceeds or is anticipated to exceed R10 million in aggregate; and

(bb) does not qualify as remuneration for purposes of the Fourth Schedule to the Income Tax Act, 1962.

The provision followed the long awaited 15\% withholding tax on service fees, which was repealed with effect from 01 January 2017 (National Treasury 2016). The withholding tax on service fees was revoked as National Treasury argued that if the two regimes were applied simultaneously, it would result in extra administrative functions for the SARS and a compliance burden for taxpayers (National Treasury 2016). The goals of both regimes are to identify undeclared permanent establishments, to collect revenue from nonresident taxpayers providing technical, management or consulting services in South Africa (National Treasury 2016) and to protect the South African tax base from extortion (National Treasury 2013). Consequently, National Treasury decided that these goals can rather be reached by the reportable arrangement regime.

However, while the aim of the foreign services reportable arrangement provision is laudable, there is cause for concern relating to its implementation. To date, no guidance relating to this provision has been issued by the SARS. Currently, there is only one guide - the Reportable Arrangement Guide, which was issued by the SARS in 2005 (SARS 2005). This guide is outdated, and still refers to the repealed section 76A of the Income Tax Act (no. 58 of 1962), which dealt with reportable arrangement rules. To the knowledge of the authors, no single consolidated source of information exists that clarifies the exact meaning of the terms used in the context of the foreign services reportable arrangement provision.

Consequently, several terms used in the foreign services reportable arrangement provision are ambiguous as they are not defined in South African tax legislation. The vagueness gives rise to uncertainties regarding the application of this provision (Gilmour 2017). The inadequate guidance provided by the SARS and limited literature available can therefore restrict the effectiveness in achieving the above intended goals, as taxpayers may raise technical points related to ambiguity of legislation to avoid reporting the arrangement. When the repealed section 76A of the Income Tax Act (the old reportable arrangement rules) came into force in 2005, the SARS admits, taxpayers raised technical points in order to avoid reporting (SARS 2008). 


\section{Research objectives}

Following the above, the primary objective of the study was to critically analyse ambiguous terms in the foreign services reportable arrangement provision. Derived from the critical analysis, the secondary objective was to determine how the monetary threshold of the provision should be determined. The final objective was to develop a decision tree that may assist taxpayers in applying the provision.

\section{Research method}

The research methodology used in this study consists of both a qualitative research approach and an empirical study. The qualitative approach will consist of a literature review. The literature reviewed includes local statutory law, relevant books, court decisions, academic articles, theses and publications by regulatory bodies.

The empirical aspect of the study utilised a survey as the research instrument.

The survey is designed to test the validity of the statements and assumptions made by the authors on the subject of determining how the term 'anticipated' should be interpreted and applied, as well as how the R10 million monetary threshold should be applied. Furthermore, the survey is designed to provide greater clarity on the ambiguities identified in this study by obtaining the opinions thereon from tax professionals in South Africa. The tax professionals surveyed were tax partners, directors and tax managers at leading audit and legal firms in South Africa.

The relevant literature and results of the survey questions are incorporated in the development of a decision tree that could be utilised by taxpayers in the identification and application of a foreign services reportable arrangement.

The research methodology of the survey research is explained at greater length in a later section.

\section{Terminology of the foreign services reportable arrangement provision Introduction}

The way in which the terminology in the provision is interpreted and applied is vital in determining whether and when an arrangement is reportable. Determining whether and when a foreign services arrangement becomes reportable is significant as any participant who fails to disclose a reportable arrangement is liable to a penalty for each month that the failure continues, limited to 12 months (section 212 of the Tax Administration Act).

Although the term 'arrangement' is defined in South African tax legislation, the terms used in the definition itself are not defined. The term 'anticipated' appears twice in the foreign services reportable arrangement provision. However, the meaning, interpretation and application of the term are not clarified in South African tax legislation. South African courts have also not yet considered its meaning and interpretation. Hence, to determine whether and when a foreign services arrangement becomes reportable, the meaning and interpretation of the terms 'arrangement' and 'anticipated' are examined to assign a meaning to the undefined terms in the context of the foreign services reportable arrangement provision. The application of the term 'anticipated' and its effect on the R10 million reporting threshold as contained in this provision are further investigated.

\section{Rules of interpretation for South African statutes}

For Botha (2005) the interpretation of a statute relates to the understanding of its legal applicability by considering the different rules and principles with regard to the interpretation of the statute. The interpretation of statutes is complex due to the fact that South African law of statutory interpretation continues to be characterised by inconsistencies and uncertainty (Clegg \& Stretch 2017). This is because South African courts tend to not apply the rules of interpretation consistently (Clegg \& Stretch 2017). It is, however, beyond the scope of this article to discuss the complexities and difficulties in interpreting fiscal legislation relating to the rules of interpretation.

South African courts apply the common law rules of interpretation when interpreting tax statutes as South African tax laws have no built-in interpretation provisions (Kafesu 2011). According to the common law rules of interpretation, the two broad approaches to the interpretation of statutes are the traditional and the modern approach (Van Schalkwyk \& Geldenhuys 2009). In the case of the traditional approach, the general theories of interpretation are literalism and intentionalism, whereas with the modern approach, the general theories to the interpretation of statutes are purposivism and contextualism (Van Schalkwyk \& Geldenhuys 2009).

De Ville (2000) states that no matter which approach to the interpretation of statutes is followed, the role of the courts is to ensure that the interpretation of statutes complies with the requirements of the Constitution. As a result, the rules of interpretation are to be derived from the Constitution.

The Constitution of the Republic of South Africa (Act no. 108 of 1996) was promulgated in 1993 and is the supreme law of South Africa (section 2 of the Constitution). Hence, section 39 of the Constitution is taken into account when interpreting tax statutes.

Sections 39(1) and (2) of the Constitution state the following:

(1) when interpreting the Bill of Rights, a court, tribunal or forum -

(a) must promote the values that underlie an open democratic society based on human dignity, equality and freedom;

(b) must consider international law; and

(c) may consider foreign law. 
(2) When interpreting any legislation, and when developing the common law or customary law, every court, tribunal or forum must promote the spirt, purport and objects of the Bill of Rights.

These Constitutional provisions compel the judiciary, when interpreting any legislation, to promote the protection of the freedom of a person, their property and the enforcement of the principles of human dignity, equality and fairness (Goldswain 2008). For Goldswain (2008), consideration of these contextual constraints and guidelines is central to the purposive approach. It therefore means that the interpreter consults external contextual factors before considering the legislative text (Botha 2005).

The modern purposive approach to the interpretation of tax statutes is already authoritative in South Africa. In Natal Joint Municipal Pension Fund v Endumeni Municipality 2 All SA 262, Wallis JA approved the modern purposive approach to the interpretation of statutes. In this case, Wallis JA expressed the view that the appropriate approach to interpretation of legislation to be followed in South Africa is:

Consideration must be given to the language used in the light of the ordinary rules of grammar and syntax; the context in which the provision appears; the apparent purpose to which it is directed and the material known to those responsible for its production. (p. 263)

Wallis JA said that from the outset, one considers the context and the language together, with neither one predominating.

Accordingly, this literature review considers their ordinary, grammatical meaning (which is found in dictionaries) and the meaning that the courts have ascribed to the terms. The applicability of the grammatical meaning and meaning assigned by the courts are further considered against the purpose and goal of the reportable arrangement provision.

Before the foreign services reportable arrangement provision can apply, an arrangement must first be entered into. As a starting point the meaning of the term 'arrangement', in the context of the provision, must be examined.

\section{Arrangement}

The term 'arrangement' is defined in section 34 of the Tax Administration Act as 'any transaction, operation, scheme, agreement or understanding (whether enforceable or not)'. The terms in this phrase are not defined in South African tax legislation.

The ordinary grammatical meaning of the terms 'transaction', 'operation', 'scheme', 'agreement' or 'understanding' are listed in Table 1.

Considering the above clarification of terms, it appears as if the legislature adopted an inclusive conceptualisation of an 'arrangement'. It can therefore be argued that the term 'arrangement' is defined in broad terms to include all forms of transactions entered into by the taxpayer.
This broad understanding of 'arrangement' and 'transaction, operation, scheme, agreement or understanding' is supported through the case of Newton $v$ FCT, 2 ALL ER 759. Lord Denning expressed the view:

The word 'arrangement' is apt to describe something less than a binding contract or agreement, something in the nature of an understanding between two or more persons. [par. 763]

This case implies that an 'arrangement' requires a conscious involvement between two or more parties who reach an understanding (De Koker \& Williams 2018). De Koker and Williams (2018) are of the opinion that there needs to be consensus or a meeting of minds between the parties to reach an understanding with regard to the terms and conditions of an arrangement.

The term 'transaction, operation or scheme' was considered in Meyerowitz v CIR (3) SA 86325 SATC 287. The Appellate Division (now the Supreme Court of Appeal) held that the word 'scheme' has an extensive meaning that is wide enough to cover a series of transactions. The court further held that it is not necessary that these transactions be in contemplation from the beginning for it to constitute a scheme (Meyerowitz $v$ CIR (3) SA 86325 SATC 287).

The courts validated the above interpretation in CIR $v$ Louw 45 SATC 113. Corbett JA held that the term 'scheme' is wide enough to cover situations in which later steps in a course of action were left unresolved at the outset. Corbett JA stated:

If there is sufficient unity between this ultimate step and what has gone before, having regard to the ultimate objective, then together they may be regarded as being part and parcel of a single scheme. (p. 135)

However, the meaning and the scope of the terms 'agreement' and 'understanding' have not yet been determined by South African courts (Loof 2013). Satumba (2011) notes that the term 'understanding' also includes any gentleman's agreement, letter of wishes or a verbal understanding.

Loof (2013) observes that the mutual distinguishing feature found in the terms 'transaction', 'operation', 'scheme', 'agreement' and 'understanding' is the element of consensus. In other words, when two or more people agree to be involved in a 'transaction, operation, scheme, agreement or understanding', it may meet the reporting criteria of the foreign services reportable arrangement provision.

TABLE 1: Dictionary definitions of terms.

\begin{tabular}{|c|c|}
\hline Term & Definition \\
\hline Transaction & $\begin{array}{l}\text { An instance of buying or selling something; the action of conducting } \\
\text { business and an exchange or interaction between people. }\end{array}$ \\
\hline Operation & The action of functioning or the fact of being active or in effect. \\
\hline Scheme & $\begin{array}{l}\text { A large-scale systematic plan or arrangement attaining some } \\
\text { particular object or putting a particular idea into effect; a secret or } \\
\text { underhand plan; a plot. }\end{array}$ \\
\hline Agreement & $\begin{array}{l}\text { A negotiated and typically legally binding arrangement between } \\
\text { parties as to a course of action. }\end{array}$ \\
\hline Understanding & An informal or unspoken agreement or arrangement. \\
\hline
\end{tabular}


This view is supported by Innes JA in the court case of Woods $v$ Walters 1921 AD 303. Innes JA held that a written agreement was not essential for a contract to be valid and enforceable. The consensus of the parties therefore does not need to be evidenced in writing.

This is affirmed by De Koker and Williams (2018). They conclude that an agreement of a proposed future transaction will constitute an 'arrangement' irrespective of whether it is in writing or not and, therefore, records all the terms and conditions or whether it is a verbal understanding.

However, as there is no physical documentation, verbal agreements or understandings may be difficult to prove. This would make it difficult for the SARS to identify a verbal arrangement, using the criteria in terms of the foreign services reportable arrangement provision.

Nonetheless, it is clear that the term 'arrangement' should be interpreted widely. This suggests that the SARS used the term 'arrangement' in an attempt to apply this provision to any possible 'transaction, operation, scheme, agreement or understanding'. This is evident by the fact that there has never been a reported case where the SARS has failed on the grounds that there was no 'transaction, operation or scheme' (Broomberg 2007).

The above view is supported when considering the context in which this provision appears. As one of the main aims of the foreign services reportable arrangement provision is to protect the South African tax base from extortion, the terms in the phrase 'transaction, operation, scheme, agreement or understanding' should be interpreted as widely as possible. This is due to the fact that the legislator would want to include all forms of arrangements to protect the South African tax base from extortion.

\section{Anticipated}

The term 'anticipated' is applied twice in the foreign services reportable arrangement provision.

The first application of this term is in section 2.6(b)(i)(bb). This section states that where it is anticipated that the nonresident will be physically present in South Africa in connection with or for the purpose of rendering the foreign services, the arrangement may, among other things, become reportable.

The second use of the term 'anticipated' is in section 2.6(b) (ii)(aa). Here it states that where it is anticipated that the expenses to be incurred will exceed R10 million in aggregate, the arrangement may, among other things, become reportable.

The Oxford English Dictionary defines the term 'anticipated' as 'regarded as probable; expect or predict' (Oxford English Dictionary [OED] 2017).
To date there remains no reported case law that deals with the application of the term 'anticipated' in the context of the foreign services reportable arrangement provision. The available literature on how the term 'anticipated' should be practically applied is therefore inadequate and restrictive.

By referring to common law principles, the authors identified likely factors that may aid in determining how the term 'anticipated' should be practically applied in the context of the foreign services reportable arrangement provision. These factors identified by the authors were included in the survey conducted for the purposes of this research.

The following factors might provide persuasive attributes to determine whether it will be anticipated that the non-resident will be physically present in South Africa in connection with or for the purposes of rendering services:

- The nature of the services.

- The terms negotiated between parties.

- The terms and conditions specified in the service level agreement (SLA).

- The history of similar services rendered in the past.

Similarly, to determine whether it is anticipated that the expenditure incurred or to be incurred will exceed R10 million in aggregate, the following factors might contribute:

- The terms negotiated between the parties involved.

- The type and length of the services to be rendered by the non-resident service provider.

- The cost of similar services rendered in the past.

It is clear from the language used in the foreign services reportable arrangement provision that the R10 million reporting threshold is applicable to all of the services rendered by the non-resident to the South African resident or non-resident with a permanent establishment in South Africa on or after 03 February 2016. This provision is not applicable on a per contract or arrangement basis. It is therefore submitted that the taxpayer will have to consider all arrangements made with the foreign service provider in order to assess whether a reporting obligation exists both in terms of whether the expenses is 'anticipated' to exceed R10 million in aggregate, as well as whether there is an 'anticipated' physical presence in South Africa.

The next subsection will examine the application of the R10 million monetary threshold as contained in the foreign services reportable arrangement provision.

\section{R10 million monetary threshold}

A requirement of the foreign services reportable arrangement provision is that the expenditure in respect of the foreign services under the arrangement incurred or to be incurred on or after 03 February 2016 exceeds or is anticipated to exceed R10 million in aggregate. This expenditure must not qualify as remuneration for purposes of the Fourth Schedule to the Income Tax Act. 
Uncertainties exist with regard to how this R10 million reporting threshold should be applied since the meaning of the term 'arrangement' and the meaning and application of the term 'anticipated' as contained in the foreign services reportable arrangement provision influence the manner in which this reporting threshold is applied. The lack of guidance from the SARS further contributes to the uncertainties.

In many cases, an agreement between parties will not only be for consultancy, construction, engineering, installation, logistical, managerial, supervisory, technical or training services but may also contain goods relating to that services, resulting in a mixed contract. To determine how this R10 million monetary threshold should be applied, it needs to be determined whether and how a mixed contract with a single composite price ought to be apportioned.

To define a mixed contract, the ordinary grammatical meaning of the terms 'mixed' and 'contract' are investigated. The Oxford English Dictionary defines the term 'mixed' as 'consisting of different qualities or elements' (OED 2017). 'Contract' is defined as 'a written or spoken agreement' (OED 2017).

Consequently, a mixed contract is for example a supply and installation agreement (supply and services), as such a contract consists of different elements (PWC 2016). A mixed contract is therefore a contract that consists of another element other than consultancy, construction, engineering, installation, logistical, managerial, supervisory, technical or training services.

It is not clear how the foreign services reportable arrangement provision should be applied in a mixed contract situation (PWC 2016). For example, it is unclear whether the contract price should be apportioned between the different components or whether the contract price as a whole should be taken into account to determine whether the arrangement is reportable.

It is imperative to determine whether the contract price should be apportioned between the different components of a mixed contract, as the contract price might exceed the reporting threshold whereas the apportioned prices for the individual supply and service do not.

A logical assumption to make is that the price of a mixed contract (specifically a supply and services contract) should be apportioned between the different components since the reportable arrangement provision is only applicable to foreign services. In terms of the provision these foreign services include consultancy, construction, engineering, installation, logistical, managerial, supervisory, technical or training services. This submission made by the authors was tested by means of a survey.

The OECD recommends that when dealing with a mixed contract one should break down the total amount payable under the contract on the basis of the information contained in the contract and then apply the appropriate tax treatment to each portion (OECD 2015b).

It is submitted that when the participant in the arrangement apportions the price of a mixed contract according to the specifications of the contract, the participant in the arrangement must be able to demonstrate to the SARS that the results of the apportionment calculation is reasonable.

\section{Conclusions made from the literature review to be tested through survey research}

The literature review studied the meaning of and reviewed ways in which the term 'anticipated', as used in the context of the foreign services reportable arrangement provision, could be interpreted and applied. A lack of a clear definition provided for uncertainties regarding the interpretation and application of the term in the context of the provision.

The meaning of the term 'anticipated' was examined by noting its ordinary, grammatical meaning: 'regarded as probable, expect or predict'.

Due to the observed dearth of existing literature on the subject, the authors identified certain factors that might contribute in determining how the term 'anticipated' should be applied in the context of the foreign services reportable arrangement provision.

When it comes to determining whether it will be anticipated that the non-resident will be physically present in South Africa, the authors submit that one can consider the nature of the services, the terms negotiated between parties, the terms and conditions specified in the SLA and the history of similar services rendered in the past.

Moreover, the authors submit that the terms negotiated between the parties involved, the type and length of the services to be rendered by the non-resident service provider and the cost of similar services rendered in the past may help in determining whether it is anticipated that the expenses incurred, or to be incurred, will exceed R10 million in aggregate.

The ordinary grammatical meaning of the terms 'mixed' and 'contract' determined that a mixed contract consists of different elements. A mixed contract therefore includes an agreement that consists of both a supply and a service element. It is submitted that the price of a mixed contract (specifically a supply and services contract) should be apportioned between the different components since the reportable arrangement provision is only applicable to foreign services.

In order to test the validity of the statements and conclusions made above, a survey was sent to a sample of tax partners, directors and managers at leading audit and legal firms.

The empirical study follows in the next section. 


\section{The empirical study Research design}

The survey research is qualitative in nature as it seeks to develop an understanding through detailed description and to build a theory that can be tested empirically in later research (Cooper \& Schindler 2008).

The research design of the survey research was modelled on both the work of Venter and Stiglingh's (2006) study and Steenkamp and Cramer's (2012) study as these two studies had the same purpose for their survey research, which was to validate the conclusions reached in the literature review against the opinions and judgements of tax and accounting professionals in South Africa.

\section{The unit of analysis and the population}

The unit of analysis consisted of highly qualified tax professionals in South Africa. The tax professionals surveyed in this study were tax partners or directors and tax managers at leading audit and legal firms. These two groups form the defined population for this study. In an attempt to increase the quality of the answers, the survey was sent to these two focused target groups. Venter and Stiglingh (2006) conducted a survey to clarify uncertainties regarding the recognition and timing of a deferred tax asset for unused secondary tax on companies credits. The survey was conducted in South Africa and was sent to accounting lecturers teaching accounting at postgraduate level at South African universities, accounting partners specialising in technical accounting matters at the eight largest auditing firms and to leading tax partners at the eight largest auditing firms in the country (Venter \& Stiglingh 2006).

In a similar vein, Steenkamp and Cramer (2012) conducted a survey to determine the completeness, accuracy and usability of an alternative model created to determine when an arrangement, as contained in sections $80 \mathrm{M}-80 \mathrm{~T}$ of the Income Tax Act, should be disclosed. The surveys were distributed to a sample of 40 tax partners at leading audit and legal firms.

Venter and Stigllingh (2006) included accounting lecturers in their study, as well as accounting partners specialising in technical accounting matters, as they were understood to be knowledgeable in accounting standards, requirements and best practice. As this study focuses on a specific tax matter and not an accounting topic, accounting lecturers and partners specialising in technical accounting matters were not included in the sample. It is expected that the inclusion of accounting lecturers and partners specialising in accounting mattes will not increase the quality of the answers received in the survey.

Steenkamp and Cramer (2012) included only tax partners or directors at leading audit and legal firms. This research differs in that tax partners or directors and managers at leading audit and legal firms were included in the research sample. It was expected that these participants were actively involved in practical tax work and hence familiar with complicated tax matters.

\section{The sample Sampling method}

This study made use of non-probability sampling. According to Cooper and Schindler (2011), there are two major types of non-probability sampling namely judgement sampling (also known as purposive sampling) and quota sampling. This study made use of judgement sampling, which is when a researcher selects their sample in accordance with some criteria (Cooper \& Schindler 2011).

As noted, one of the criteria of the foreign services reportable arrangement provision is that the expenditure incurred or to be incurred is anticipated to exceed R10 million in aggregate. It would be expected that larger established companies (based on income earned and size) are more likely to conclude service contracts with non-residents where the expenditure is expected to exceed R10 million in total. For this reason the authors surveyed tax professionals involved in providing tax advice for these larger companies.

Hence, the tax professionals surveyed were tax partners, directors and tax managers at leading audit and legal firms, as they provide tax advice for larger companies. With many years of practical first-hand experience in complicated technical tax matters, it is expected that they have in-depth knowledge of the workings of the foreign services reportable arrangement provision and would be appropriate to provide insight into how this provision should be interpreted and applied.

Non-probability sampling, specifically judgement sampling, is therefore considered to be both appropriate and adequate for this empirical study as the sample selected conform to the above criteria.

A limitation or restriction of judgement sampling (also known as purposive sampling) is that other experts would likely come up with different elements from the target population in terms of key features and typical components to be in the sample (Battaglia 2011). Another limitation of purposive sampling is that the researcher runs the risk of introducing unknown bias as it assumes that the researcher knows in advance what the relevant key features are (Vogt 2011). However, judgement sampling is often the only solution to increase representativeness in field research and it can be an improvement over simple convenience sampling (Battaglia 2011).

\section{Sample selection}

The study included a total sample size of 20 firms, which comprises 15 audit firms and 5 legal firms. 
A listing of the top 15 audit firms in the world, based on available fee income figures for 2016 was obtained from the International Accounting Bulletin (2017). All the top 15 audit firms had offices in South Africa. These 15 firms are listed in Table 2.

The legal firms were included in the sample as they specialise in providing tax and legal advice for their clients. The five largest legal firms in South Africa were selected based on the most recent available data reflecting the number of attorneys in their employ at the time the survey was administered. The information was obtained from Wikipedia (2017), who combined the information of major South African legal firms by using data from their websites to compile a listing of the rankings. The use of Wikipedia was deemed appropriate, as it followed Steenkamp and Cramer's (2012) study. The legal firms included in the study are listed in Table 3.

One tax partner, director or manager was identified per firm to complete the survey. This was deemed appropriate as the respondent identified to complete the survey was seen as the expert in the field of reportable arrangements in the applicable firm. The tax partners, directors and managers of the leading audit and legal firms in South Africa were identified by the information contained on their websites and contacted via email to request their participation in the survey. The tax partners, directors and managers were asked to identify an expert in the field of reportable arrangements if they felt they weren't the most suitable person to complete the survey.

Some of the targeted respondents who were unable to participate in the survey due to time constraints, provided contact details of an appropriate tax partner, director, manager or other staff member with similar experience.

TABLE 2: The 15 audit firms, in alphabetical order, that were included in the sample.

\begin{tabular}{ll}
\hline Number & Organisation name \\
\hline 1 & Baker Tilly International \\
2 & BDO \\
3 & Crowe Horwath International \\
4 & Deloitte \\
5 & Earnest \& Young \\
6 & Grant Thornton \\
7 & HLB International \\
8 & Kreston International \\
9 & KPMG \\
10 & Mazars \\
11 & Moore Stephens International \\
12 & Nexia International \\
13 & PKF \\
14 & PricewaterhouseCoopers \\
15 & RSM \\
\hline
\end{tabular}

TABLE 3: The five legal firms, in alphabetical order, that were included in the sample. \begin{tabular}{l} 
Num \\
\hline 1 \\
2 \\
3 \\
4 \\
5
\end{tabular} Organisation name

Bowmans

Cliffe Dekker Hofmeyr

ENSafrica

Norton Rose Fulbright South Africa

Webber Wentzel
As the respondents are experts in the field of tax, the total sample size of 20 firms (one respondent per firm) was deemed appropriate.

\section{Background to the survey}

Before the research commenced, ethical clearance was obtained from Human Research Ethics at Stellenbosch University. The survey was web-based and developed using SunSurveys. The respondents first received an email with an extract of the foreign services reportable arrangement provision. A link to the survey was then distributed to the respondents via email through the use of SunSurveys. The respondents first gave informed consent before the survey commenced. The respondents completed the survey directly on SunSurveys. The same sample of respondents was used to answer all the survey questions.

Respondent confidentiality was ensured in the survey. The survey did not require the disclosure of any personal information, and hence survey responses cannot be linked to individual respondents.

\section{Profile of respondents}

The profiles of the respondents are shown in Table 4.

As Table 4 reveals, $43 \%$ of the respondents are either partners or directors at their respective audit or legal firms, while $43 \%$ are tax managers. The 'other' category refers to staff members who had practical experience with the foreign services reportable arrangement provision. Where the tax partner, director or manager was unable to complete the survey due to time constraints, the survey was forwarded to an appropriate 'other' staff member.

As Table 5 demonstrates, $36 \%$ of the respondents have less than 10 years' experience working in the field of South African tax legislation. Altogether $14 \%$ of the respondents have between 10 and 15 years' experience working with South African tax legislation and $50 \%$ of the respondents have more than 15 years' experience with South African tax legislation.

The results regarding the experience of these tax professionals are shown in Table 5.

TABLE 4: Profile of respondents.

\begin{tabular}{lcc}
\hline Role & Actual number of responses & Total (\%) \\
\hline Tax director & 4 & 29 \\
Tax partner & 2 & 14 \\
Tax manager & 6 & 43 \\
Other & 2 & 14 \\
\hline Total & $\mathbf{1 4}$ & $\mathbf{1 0 0}$
\end{tabular}

TABLE 5: Work experience of respondents.

\begin{tabular}{lc}
\hline Years of experience & Total (\%) \\
\hline$<10$ & 36 \\
$10-15$ & 14 \\
$>15$ & 50 \\
\hline
\end{tabular}


The majority (64\%) of the respondents have at least 10 years' experience working with South African tax legislation. It can therefore be expected, considering the skills and experience of the respondents, that their responses add credibility to the results of the survey and enhance the reliability of this research study.

\section{Response rate}

Of the 20 surveys disseminated, 14 surveys were completed, resulting in a response rate of $70 \%$. The response rate of $70 \%$ was considered satisfactory as the majority $(64 \%)$ of the respondents had at least 10 years' experience working with South African tax legislation.

The respondents' response to the survey questions are statistically summarised next.

\section{Statistical summary of the results}

Tables 6-10 set out the results of the responses received to the survey.

\section{Unclear meaning of the term 'anticipated'}

Respondents were asked whether they agreed that the meaning and application of the term 'anticipated' is unclear.

The survey results confirmed the conclusion drawn from the literature review, namely that the meaning and application of the term 'anticipated' is unclear as the term is not defined in South African tax legislation. As Table 6 demonstrates, a clear majority of respondents $(64 \%)$ agreed or totally agreed that neither the Tax Administration Act, nor the Income Tax Act nor the SARS provides clarity on how the term 'anticipated' should be interpreted and applied.

\section{The term 'anticipated' can be interpreted as 'regarded as probable, expect or predict?'}

As Table 7 demonstrates, all of the respondents (100\%) supported the conclusion drawn from the literature review, namely that the term 'anticipated' can be interpreted by looking at the ordinary grammatical meaning, that is, 'regarded as probable, expect or predict'. Therefore, among other things, when it is expected, predicted or

TABLE 6: Results of whether the term 'anticipated' is unclear.

\begin{tabular}{lccccc}
\hline Response & $\begin{array}{c}\text { Tax director } \\
(\boldsymbol{n}=\mathbf{4})\end{array}$ & $\begin{array}{c}\text { Tax partner } \\
(\boldsymbol{n}=\mathbf{2})\end{array}$ & $\begin{array}{c}\text { Tax manager } \\
(\boldsymbol{n}=\mathbf{6})\end{array}$ & $\begin{array}{c}\text { Other } \\
(\boldsymbol{n}=\mathbf{2})\end{array}$ & $\begin{array}{c}\text { Total } \\
(\boldsymbol{N}=\mathbf{1 4})\end{array}$ \\
\hline Totally agree & 1 & 1 & 2 & - & 4 \\
Agree & 2 & 1 & 3 & 2 & 8 \\
Neutral & - & - & 1 & - & 1 \\
Disagree & 1 & - & - & - & 1 \\
Totally disagree & - & - & - & - & - \\
\hline
\end{tabular}

TABLE 7: Results of the meaning of the term 'anticipated'.

\begin{tabular}{lccccc}
\hline Response & $\begin{array}{c}\text { Tax director } \\
(\boldsymbol{n}=\mathbf{4})\end{array}$ & $\begin{array}{c}\text { Tax partner } \\
(\boldsymbol{n}=\mathbf{2})\end{array}$ & $\begin{array}{c}\text { Tax manager } \\
(\boldsymbol{n}=\mathbf{6})\end{array}$ & $\begin{array}{c}\text { Other } \\
(\boldsymbol{n}=\mathbf{2})\end{array}$ & $\begin{array}{c}\text { Total } \\
(\boldsymbol{N}=\mathbf{1 4})\end{array}$ \\
\hline Yes & 4 & 2 & 6 & 2 & 14 \\
No & - & - & - & - & - \\
\hline
\end{tabular}

estimated that the non-resident will be physically present in South Africa or when it is expected, predicted or estimated that the arrangement will exceed R10 million in aggregate, a reporting obligation may exist.

\section{Factors to determine anticipated physical presence}

Respondents were asked to indicate which factors can help determine whether it is anticipated that a non-resident service provider will be physically present in South Africa in connection with or for the purposes of rendering those services. The results are shown in Table 8.

These results validate the assertion that the above factors can help determine whether it is anticipated that the non-resident service provider will be physically present in South Africa in connection with or for the purpose of rendering those services.

Table 8 shows that all the respondents (100\%) agreed that considering the nature of the services that will be rendered by the non-resident can help to determine whether it is anticipated that a non-resident service provider will be physically present in South Africa. Moreover, all respondents agreed that one may determine whether it is anticipated that the non-resident service provider will be physically present in South Africa by looking at the history of similar services rendered in the past by the non-resident to any resident or non-resident with a permanent establishment in South Africa.

Thirteen respondents agreed that the terms and conditions specified in the SLAs between the non-resident and South African resident (or non-resident with a permanent establishment in South Africa) can provide an indication as to whether one may anticipate a non-resident's physical presence in South Africa.

Three respondents agreed that one can anticipate whether the non-resident will be physically present in South Africa by looking at the terms negotiated between the non-resident and South African resident or non-resident with a permanent establishment in South Africa.

None of the respondents identified any other possible factors that may determine how the term 'anticipated' should be applied.

\section{Factors to determine total anticipated service expense}

The survey results validate the factors proposed to aid in the determination of whether one can anticipate that the service expense incurred or to be incurred will exceed R10 million in aggregate. As Table 9 demonstrates, $71 \%$ of the respondents agreed that the following two factors can help determine whether the expenses incurred or to be incurred will exceed R10 million in aggregate: (1) the terms negotiated between the non-resident service provider and the South African resident or non-resident with a permanent establishment 
in South Africa and (2) the type of service to be rendered, as well as the length of the service to be rendered by the nonresident service provider.

Thirteen of the respondents agreed that one can anticipate whether the expenses incurred or to be incurred would exceed R10 million in aggregate by looking at the cost of similar services rendered in the past.

Three respondents (a tax partner, tax manager and other) noted other factors which could aid in anticipating whether the expenses incurred or to be incurred would exceed R10 million in aggregate. Their responses are summarised as follows:

- A tax partner noted that one can look at the extent of the work and what similar service providers will charge for similar services.

- A tax manager noted that one can inspect contractual terms (liability for overruns). The contractual terms will specify which party is responsible to pay any overruns. If the South African resident (or non-resident with a permanent establishment in South Africa) is responsible for paying the overruns, this will increase the foreign service expense which then may exceed the R10 million reporting threshold.

- A senior staff member noted that it would depend on the relevant individual circumstances of each transaction.

\section{Apportioning of a mixed contract}

As Table 10 demonstrates, the vast majority of the respondents (93\%) agreed with the statement made in the literature review that a mixed supply contract (specifically a supply and services arrangement) with a single composite price should be apportioned between the services and non-service component for the purposes of the foreign services reportable arrangement provision.

\section{Findings of the empirical study}

The majority of the respondents agreed that the meaning and application of the term 'anticipated' is unclear as neither the Tax Administration Act, Income Tax Act nor the SARS provides clarity on how it should be interpreted and applied.

All of the respondents agreed that, in the context of the foreign services reportable arrangement provision, the term 'anticipated' can be interpreted by looking at its ordinary grammatical meaning.

The respondents agreed that the factors identified by the authors may aid in determining whether it is anticipated that the non-resident service provider will be physically present in South Africa in connection or for purposes of rendering services.

The respondents agreed that the factors identified by the authors may aid in determining whether it is anticipated that the expenses incurred or to be incurred will exceed R10 million in aggregate. Respondents further noted that one can look at the extent of the work and what similar service providers will charge for similar services and one can inspect contractual terms to determine who is responsible to pay for any overruns.

The respondents agreed that a mixed contract with a single composite price should be apportioned for purposes of the foreign services reportable arrangement provision.

TABLE 8: Results of contributing factors that help in determining anticipated physical presence.

\begin{tabular}{|c|c|c|c|c|c|}
\hline Factor & $\begin{array}{l}\text { Tax director } \\
(n=4)\end{array}$ & $\begin{array}{l}\text { Tax partner } \\
(n=2)\end{array}$ & $\begin{array}{c}\text { Tax manager } \\
(n=6)\end{array}$ & $\begin{array}{l}\text { Other } \\
(n=2)\end{array}$ & $\begin{array}{c}\text { Total } \\
(N=14)\end{array}$ \\
\hline The nature of the services that will be rendered by the non-resident service provider. & 4 & 2 & 6 & 2 & 14 \\
\hline $\begin{array}{l}\text { The terms negotiated between the non-resident service provider and South African resident or non- } \\
\text { resident with a permanent establishment in South Africa. }\end{array}$ & 2 & 1 & 4 & 1 & 8 \\
\hline The terms and conditions specified in the service level agreement (draft or final agreements). & 3 & 2 & 6 & 2 & 13 \\
\hline $\begin{array}{l}\text { History of similar services rendered in the past by the non-resident service provider to any resident or } \\
\text { non-resident with a permanent establishment in South Africa. }\end{array}$ & 4 & 2 & 6 & 2 & 14 \\
\hline Other: Please elaborate. & 0 & 0 & 0 & 0 & 0 \\
\hline
\end{tabular}

TABLE 9: Results of the contributing factors that help in determining the total anticipated service expense.

\begin{tabular}{|c|c|c|c|c|c|}
\hline Factor & $\begin{array}{c}\text { Tax director } \\
(n=4)\end{array}$ & $\begin{array}{c}\text { Tax partner } \\
(n=2)\end{array}$ & $\begin{array}{c}\text { Tax manager } \\
(n=6)\end{array}$ & $\begin{array}{l}\text { Other } \\
(n=2)\end{array}$ & $\begin{array}{c}\text { Total } \\
(n=14)\end{array}$ \\
\hline $\begin{array}{l}\text { The terms negotiated between the non-resident service provider and South African resident or non- } \\
\text { resident with a permanent establishment in South Africa. }\end{array}$ & 3 & 2 & 4 & 1 & 10 \\
\hline Cost of similar services rendered in the past. & 4 & 2 & 6 & 1 & 13 \\
\hline Other: Please elaborate. & 0 & 1 & 1 & 1 & - \\
\hline
\end{tabular}

TABLE 10: Results of whether a mixed contract should be apportioned.

\begin{tabular}{|c|c|c|c|c|c|}
\hline Response & $\begin{array}{c}\text { Tax director } \\
(n=4)\end{array}$ & $\begin{array}{c}\text { Tax partner } \\
(n=2)\end{array}$ & $\begin{array}{c}\text { Tax manager } \\
(n=6)\end{array}$ & $\begin{array}{l}\text { Other } \\
(n=2)\end{array}$ & $\begin{array}{c}\text { Total } \\
(n=14)\end{array}$ \\
\hline Yes, the mixed supply contract should be apportioned between the supply and services component. & 4 & 2 & 5 & 2 & 13 \\
\hline No, the contract price as a whole should be taken into account. & - & - & 1 & - & 1 \\
\hline
\end{tabular}




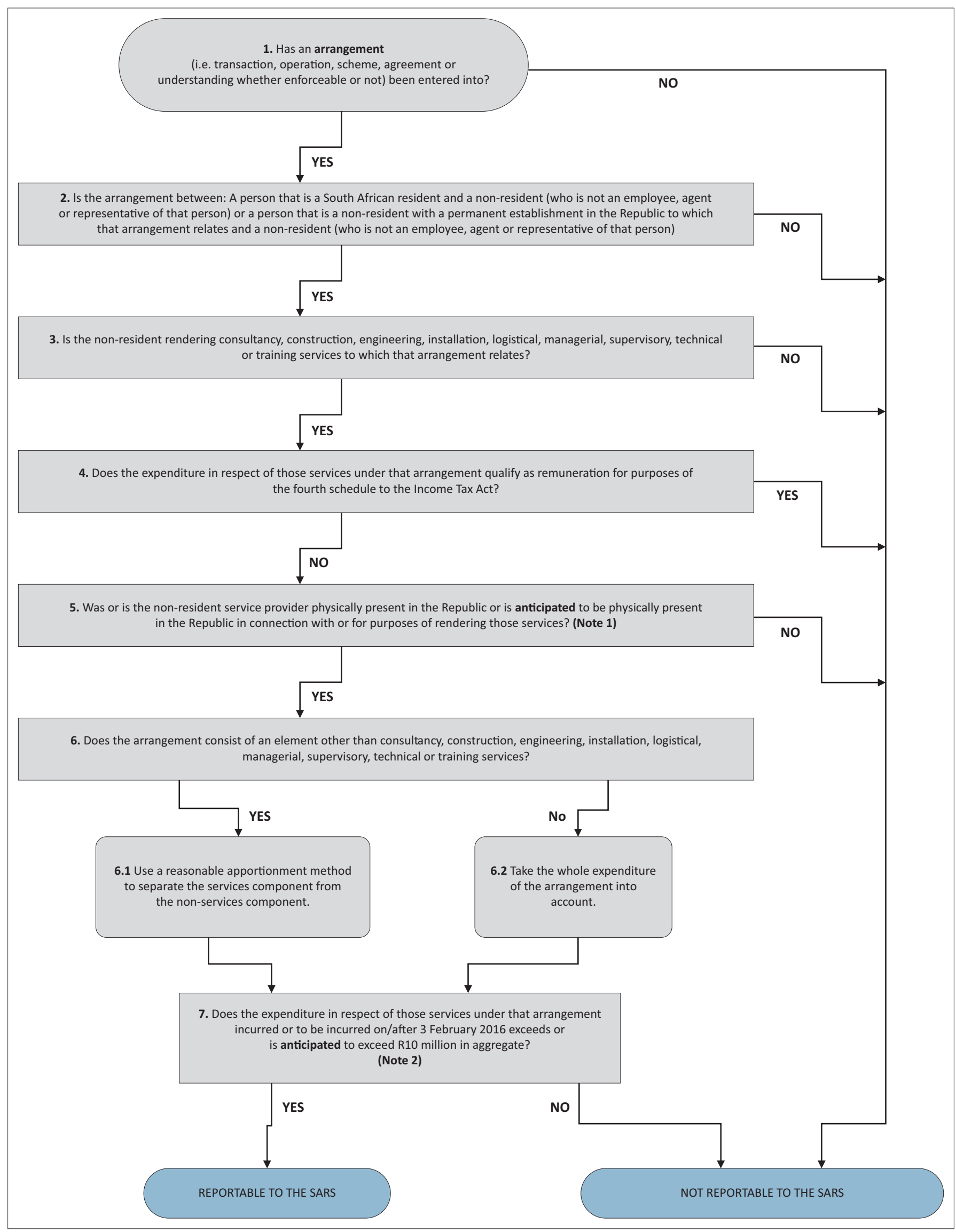

FIGURE 1: Decision tree. 
The literature review and survey results are incorporated to develop a decision tree.

The decision tree, together with the literature review, can be used by National Treasury when updating the Reportable Arrangement Guide or when issuing an Interpretation Note for the foreign services reportable arrangement provision.

The summarised literature review and decision tree from this study could also be utilised by taxpayers in the identification of a foreign service reportable arrangements. This could be of value to taxpayers when considering the tax implications of this reportable arrangement provision. This decision tree may also provide clarity to taxpayers on how this provision should be applied in practice. The decision tree can be seen in Figure 1.

Note 1: The following factors may aid in determining whether it will be anticipated that the non-resident service provider will be physically present in South Africa in connection with or for the purposes of rendering services:

- The nature of the services.

- Terms negotiated between parties.

- The terms and conditions specified in the SLA.

- The history of similar services rendered in the past.

Note 2: The following factors may aid in determining whether it will be anticipated that the expenses incurred or to be incurred will exceed R10 million in aggregate:

- The terms negotiated between the parties involved.

- The type and length of the services to be rendered by the non-resident service provider.

- The cost of similar services rendered in the past.

- The extent of the work and what similar service providers will charge for similar services.

- The contractual terms (liability for overruns).

\section{Conclusion}

The goal for the SARS with the implementation of the foreign services reportable arrangement provision was to identify undeclared permanent establishments, to collect revenue from non-resident taxpayers who provide services in South African and to protect the South African tax base from extortion. The inadequate guidance provided by the SARS and limited literature available about this provision restrict the effectiveness in achieving the above goals. It was determined that without clear guidance, there is a danger that the interpretation of undefined terms will be subjective, which could lead to uncertainty pertaining to the correct application of the provision.

The objective of this study was therefore to critically analyse the foreign services reportable arrangement provision by assigning meaning to some of the undefined terms in the provision and to develop a decision tree that may assist taxpayers in applying the provision.
The analysis of the term 'arrangement' indicated that this term should be defined in broad terms as the SARS used this term in an attempt to apply the foreign services reportable arrangement provision to any possible 'transaction, operation, scheme, agreement or understanding'.

An analysis of the term 'anticipated' supported by the survey research determined that this term can be defined as 'regarded as probable, expect or predict'. Several factors were confirmed to have an influence in determining whether it is anticipated that the non-resident will be physically present in South Africa in connection with or for the purposes of rendering services. These factors include the nature of the services, terms negotiated between parties, the terms and conditions specified in the SLA and the history of similar services rendered in the past. This study was also able to confirm that various factors could assist in determining whether it is anticipated that the expenses incurred or to be incurred, will exceed R10 million in aggregate. Participants may look to the terms negotiated between the parties involved, the type and length of the services to be rendered by the non-resident and the cost of similar services rendered in the past.

The research concluded that the contract price of a mixed contract (specifically a supply and services contract) ought to be apportioned between its different components, as the 'supply' portion of the contract does not fall within the ambit of a 'service'. The manner in which the contract price is apportioned between the different components will depend on the specifications of the contract. The participant in the arrangement must, however, be able to demonstrate, on request, to the satisfaction of SARS that the result of the apportionment calculation is reasonable.

It is recommended that SARS issue an updated guide or interpretation note on the application of the foreign services reportable arrangement provision as evidence from the study indicates that uncertainties exist in practice.

\section{Acknowledgements Competing interests}

The authors have declared that no competing interests exist.

\section{Authors' contributions}

All authors contributed equally to this work.

\section{Ethical consideration}

Stellenbosch University Research Ethics Committee (REC) Humanities, Ethical Clearance Number: 6381, 05 April 2018.

\section{Funding information}

This research achieved no specific grant from any funding agency in the public, commercial or not-for-profit sectors. 


\section{Data availability statement}

Survey results are available.

\section{Disclaimer}

The views and opinions expressed in this article are those of the authors and do not necessarily reflect the official policy or position of any affiliated agency of the authors.

\section{References}

Battaglia, P., 2011, Encyclopedia of survey research methods, Sage, viewed 25 February 2020, from https://methods-sagepub-com.ez.sun.ac.za/reference/ the-sage-encyclopedia-of-social-science-research-methods $/ \mathrm{n} 774 . \mathrm{xml}$ ? fromsearch=true.

Botha, C., 2005, Statutory interpretation: An introduction for students, 4th edn., Juta \& Co Ltd., Lansdowne.

Broomberg, E., 2007, 'Then and Now II', Tax Planning Corporate and Personal 21(6), viewed 12 November 2018, from Lexis Nexis South Africa.

CIR v Louw 1983, 45 SATC 113 (1983) Appellate Division.

Clegg, D. \& Stretch, R., 2017, Income tax in South Africa, viewed 11 January 2018, https://www.mylexisnexis.co.za/Index.aspx?permalink=Q2ggMiBwYXIgMi40Ljlk NDc3MDUOJDckTGlicmFyeSRKRCRMaWJyYXJ5.

Cooper, D. \& Schindler, P., 2008, Business research methods, 9th edn., McGraw-Hill, New York, NY.

Cooper, D. \& Schindler, P., 2011, Business research methods, 11th edn., McGraw-Hill, New York, NY.

Davis Tax Committee, 2014, Addressing base erosion and profit shifting in South Africa Davis Committee Interim Report 1-39, DTC, Pretoria.

De Koker, A. \& Williams, R., 2018, Silke on South African Income Tax, Lexis Nexis, viewed 15 March 2018, from https://www.mylexisnexis.co.za/Index.aspx?perma ink=Q2ggMTkgcGFyIDE5LjM2JDI2NTMxMzIkNyRMaWJyYXJ5JEpEJExpYnJhcnk.

De Ville, J.R., 2000, Constitutional and statutory interpretation, Interdoc Consultants, Cape Town.

ENS Africa, 2015, '2429. Cross-border service arrangements', Integritax (190), 1-4, viewed 08 April 2018, from https://www.saica.co.za/integritax/2015/2429. Cross-border_service_arrangements.htm.

Gilmour, S., 2017, South Africa: The spectre of withholding tax on service fees finally laid to rest, viewed 08 March 2020, from https://www.internationaltaxreview. com/article/b1f7n64x0dsdc6/south-africa-the-spectre-of-withholding-tax-onservice-fees-finally-laid-to-rest.

Goldswain, G.K., 2008, 'The purposive approach to the interpretation of fiscal legislation - The winds of change', Meditari Accountancy Research 16(2), 107-121. https://doi.org/10.1108/10222529200800015

International Accounting Bulletin, 2017, 'World survey: What an uncertain world', International Accounting Bulletin 2(570), 4-6.

Kafesu, L., 2011, 'Interpretation of fiscal statutes by the courts: A South African Tax Law perspective', Unpublished Master's dissertation, University of Cape Town Cape Town.

Loof, G., 2013, 'A critical analysis of the requirements of the South African General Anti-avoidance Rule', Unpublished Master's dissertation, University of Cape Town, Cape Town

Meyerowitz v CIR 25 SATC 287 (1963) Appellate Division.
Natal Joint Municipal Pension Fund v Endumeni Municipality [2012] 2 ALL SA 262 (SCA) (2012) Supreme Court of Appeal.

National Treasury, 2013, Explanatory memorandum on the Taxation Laws Amendment Bill, 2013, viewed 15 October 2017, from https://www.sars.gov.za/AllDocs/ LegalDoclib/ExpIMemo/LAPD-LPrep-EM-2013-02\%20-\%20Explanatory\%20 Memorandum\%20Taxation\%20Laws\%20Amendment\%20Bill\%202013.pdf.

National Treasury, 2016, Explanatory memorandum on the Taxation Laws Amendment Bill 17B of 2016, viewed 18 January 2018, from: https://www.sars gov.za/AllDocs/ LegalDoclib/ExpIMemo/LAPD-LPrep-EM-2016-02\%20-\%20EM\%20on\%20the\%20 Talion\%20Laws\%20Amendment\%20Bill\%2017B\%20f\%202016\%2015\%20 December\%202016.pdf.

National Treasury, 2017, Budget review 2017, viewed 28 August 2017, from http:// www.treasury.gov.za/documents/national budget/2017/review/FullBR.pdf.

Newton and Others v FCT, 2 All ER 759 (1958) Privy Council.

OECD, 2013, Addressing base erosion and profit shifting, OECD Publishing, Paris, viewed 06 March 2020, from https://doi.org/10.1787/9789264192744-en

OECD, 2015a, Mandatory disclosure rules, Action 12 - 2015, OECD Publishing, Paris, viewed 25 January 2018, from https://doi.org/10.1787/9789264241442-en

OECD, 2015b, Model Tax Convention on income and on capital 2014 (full version), OECD Publishing, Paris, viewed 14 November 2017, from https://doi.org/10. 1787/9789264239081-en

Oxford English Dictionary (OED), 2017, Oxford English Dictionary Online, viewed 27 October 2017, from https://en.oxforddictionaries.com/definition.

PWC, 2016, Foreign services reportable arrangements giving rise to uncertainties, viewed 25 August 2017, from https://www.pwc.co.za/en/assets/pdf/synopsis/ synopsis-june-2016.pdf.

South African Revenue Service (SARS), 2005, Reportable arrangement guide, viewed 10 April 2017, from http://www.sars.gov.za.

South African Revenue Service (SARS), 2008, Media release: New reportable arrangements legislation takes effect, viewed 08 March 2020, from https://www. sars.gov.za/AllDocs/Documents/MediaReleases/2008/SARS-MR-2008-012\%20 -\%20Media\%20Release\%20on\%20New\%20reportable\%20arrangements\%20 legislation\%20takes\%20effect\%20-\%209\%20April\%202008.pdf.

South African Revenue Service (SARS), 2016, Government Gazette Staatskoerant no. 39650, vol. 608, viewed 05 April 2017, from http://www.sars.gov.za.

Satumba, R., 2011, 'An analysis of the General Anti-avoidance Rule in South Africa in comparison with foreign anti-avoidance provisions', Unpublished Master's dissertation, University of Pretoria, Pretoria.

South Africa, 1962, The Income Tax Act No. 58 of 1962, Government Printer, Pretoria.

South Africa, 2011, The Tax Administration Act No. 28 of 2011, Government Printer, Pretoria.

Steenkamp, L. \& Cramer, P., 2012, 'A critical analysis of the current SARS model for the disclosure of reportable arrangements', Journal of Economic and Financial Sciences 5(2), 391-416. https://doi.org/10.4102/jef.v5i2.291

Van Schalkwyk, L. \& Geldenhuys, B., 2009, 'Section 80A(c)(ii) of the Income Tax Act and the interpretation of tax statutes in South Africa', Meditari Accountancy Research 17(2), 167-185. https://doi.org/10.1108/10222529200900018

Venter, E.R. \& Stiglingh, M., 2006, 'Recognising an STC liability versus recognising a deferred tax asset for unused STC credits according to the IASB framework: A comparison', Meditari Acountancy Research 14(1), 103-120. https://doi.org/10. 1108/10222529200600007

Vogt, P., 2011, Dictionary of statistics and methodology, Sage, viewed 25 February 2020 , from https://methods-sagepub-com.ez.sun.ac.za/reference/dictionary-ofstatistics-methodology/n1547.xml?fromsearch=true.

Wikipedia, 2017, Big five (law firms) in South Africa, viewed 02 February 2018, from https://en.wikipedia.org/wiki/Big_Five_(law_firms)_in_South_Africa.

Woods Appellant v Walters Respondent 1921 AD (1921) Appellate Division. 